\title{
Inotropic agents for heart failure: what if digoxin increases mortality?
}

\author{
Sticares \\ Cardiovascular \\ Research Foundation, \\ Rotterdam, The \\ Netherlands \\ W J Remme \\ Correspondence to: \\ Dr W J Remme, \\ Sticares Foundation, $\mathrm{PO}$ \\ Box 52006, 3007 LA \\ Rotterdam, The \\ Netherlands.
}

In recent years the approach to heart failure has changed from one that focused on the haemodynamic changes at the basis of the syndrome or occurring as a result of it to one that recognises the significance of neuroendocrine activation not only for the occurrence of heart failure but also for its clinical expression and ultimate prognosis. Moreover, the fact that heart failure depends not only on cardiac changes but to a large extent on intrinsic peripheral changes has been gradually appreciated.

Consequently, the management of heart failure has taken a different turn, focusing now on modulation of neuroendocrine activation and other extracardiac abnormalities rather than trying to increase cardiac contractile force through positive inotropic treatment. This attitude has been reinforced by current doubts about the clinical efficacy and safety of positive inotropic treatment. As other physiologically more relevant treatments such as inhibition of angiotension converting enzyme have become available, it is not so much a question of when positive inotropic agents should be administered but whether there is in fact a place and need for this form of treatment.

In most patients, however, cardiac contractile dysfunction is the primary disorder and the origin of the heart failure, so intuitively, pharmacological interventions aimed at inotropic support have been considered important in treating heart failure for many years. Consequently, many inotropic agents have been developed. Positive inotropic drugs are categorised as cyclic AMP (cAMP) dependent or cAMP independent.

\section{Cardiac contractile force and contractility: how to manipulate it? CAMP DEPENDENT MECHANISMS}

Whether they act through cAMP or not, inotropic drugs increase cardiac contractile force by altering the availability of calcium to the contractile proteins and by altering the interaction of calcium with the troponintropomyosin complex. In addition, cAMP dependent agents influence the velocity of contractile protein interaction and the sequestration of calcium from the cytosol after contraction.

cAMP formation depends on the activity of the adenylate cyclase system, which, in turn, depends on activation of stimulatory $\beta$ adrenergic versus inhibitory muscarinic or adenosine receptors and on the activity of stimulatory versus inhibitory regulating proteins, the $\mathrm{G}$ proteins (fig 1). Once formed, cAMP is degraded to 5-AMP under the influence of soluble or membrane bound cGMP inhibited, cAMP specific phosphodiesterases of subtype III.

In the heart an increase of this second messenger leads to cAMP dependent phosphorylation of certain protein kinases, which affect the contraction-relaxation process in several ways. Firstly, the slow inward calcium current is increased through voltage dependent L type channels in the sarcolemma. This calcium is instrumental in the subsequent release of larger amounts of calcium from the sarcoplasmic reticulum into the cytosol at the contractile protein site. The degree of calcium induced calcium release determines the force of contraction.

Secondly, the concentration of cAMP is pivotal for myofibrillar ATPase activity and crossbridging cycling rate, and, hence, for contractility.

Finally, cAMP influences relaxation in various ways. Phosphorylation of phospholamban enhances calcium reuptake by the sarcoplasmic reticulum, whereas phosphorylation of troponin I reduces the calcium sensitivity of troponin C, both mechanisms enhancing cardiac relaxation.

\section{CAMP INDEPENDENT MECHANISMS}

There are several additional ways to interfere with cardiac contraction without affecting cAMP concentrations. Again, in these cAMP independent mechanisms calcium plays a central part. Experimental conditions which increase the intracellular calcium concentration directly or indirectly by introducing paired stimulation enhance contractile force in parallel with the change in inward calcium current. ${ }^{1}$ For instance, $\alpha_{1}$ adrenergic receptor stimulation increases inositol 1,4,5-triphosphate (IP3) concentrations, subsequently enhancing the inward calcium current and contractile force, whereas sarcolemmal calcium agonists may increase force by directly opening the calcium channels-for example, Bay K $8644 .^{2}$ However, potentially more relevant mechanisms in terms of pharmacological modulation of intracellular calcium relate to either sarcolemmal sodium channel stimulation or to sarcolemmal sodiumpotassium ATPase inhibition (digitalis glycosides), the latter indirectly raising the concentration of intracellular calcium ions through increased sodium influx with subsequent sodium-calcium exchange.

A different approach towards increasing contractility is not to increase the 


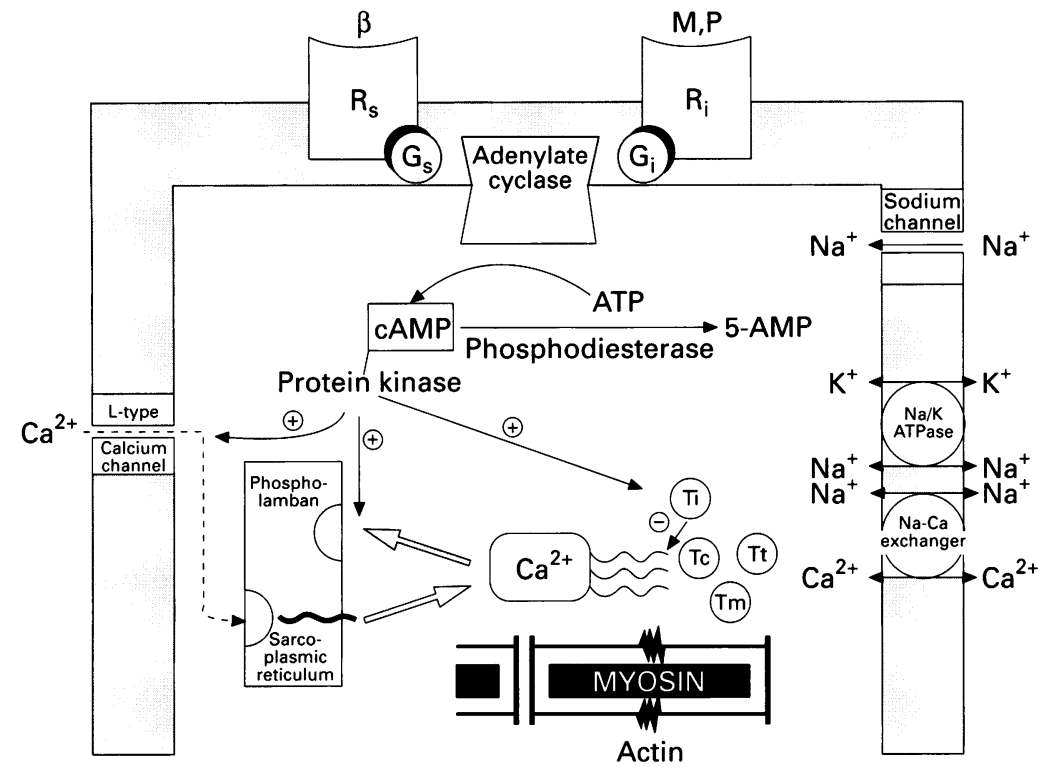

Figure 1 Schematic representation of cardiac cyclic $A M P$ (cAMP) formation and its interaction with contraction and relaxation. cAMP, formed after activation of the $\beta$ receptor(Rs)-Gs-adenylate cyclase axis, stimulates several protein kinases, subsequently enhancing sarcolemmal calcium fluxes, which release calcium from intracellular stores, such as the sarcoplasmatic reticulum. Binding of calcium with the troponin-tropomyosin complex (Ti, Tc, Tm, Tt) leads to actin-myosin interaction and contraction. Subsequent sequestration of cytosolic calcium into the sarcoplasmic reticulum and relaxation is enhanced by cAMP induced phosphorylation of protein kinases that affect the activity of phospholamban and Ti. CAMP is degraded to 5-AMP under the influence of cytosolic and particulate cyclic nucleotide phosphodiesterases. (M, muscarinic; $P$, purinergic; Ri, inhibitory receptor; $G i$, inhibitory $G$ protein.)

concentration of calcium but to enhance the sensitivity of the contractile apparatus-that is, of troponin $\mathrm{C}$-for the available calcium. Cardiac contraction is governed by three mechanisms: increase in intracellular calcium concentration, the binding of calcium to troponin $\mathrm{C}$, and subsequent alteration of molecular conformation of the myofibrils. Calcium occupancy of troponin $C$ is determined by the ratio of the rates of association and dissociation of calcium. As it is the latter which is affected by manoeuvres that improve calcium sensitivity, it follows that, as a consequence, relaxation may slow down. ${ }^{3}$

Calcium sensitisation is potentially an interesting approach to positive inotropic support in heart failure. Apparently, it is more economical and less energy consuming to increase contractile force than increase the intracellular concentration of calcium, particularly by cAMP dependent mechanisms-for example, with agents such as isoprenaline and the predominant phosphodiesterase inhibitors, such as enoximone. ${ }^{4}$ The reasons are twofold. Firstly, the energy required for calcium recycling increases with higher inward calcium currents. Secondly, myofibrillar ATPase activity is amplified with cAMP dependent inotropic mechanisms. By contrast, increasing cardiac force by enhanced calcium sensitivity or enhanced maximum calcium activated force avoids this extra myocardial energy consumption.

Moreover, calcium sensitisation may be preserved in progressive heart failure, ${ }^{5}$ despite the fact that ionic conditions such as acidosis and increased phosphate concentrations, ${ }^{6}$ prevalent in ischaemia and possibly also in ischaemic cardiomyopathy and end stage heart failure, negatively affect calcium sensitivity. In contrast, cAMP dependent contractile effects become progressively less during the later stages of heart failure. ${ }^{78}$

\section{Intrinsic cardiac changes during heart failure that affect pharmacological inotropic interventions}

Secondary to the enhanced sympathetic stimulation in heart failure, sarcolemmal $\beta$ receptor density decreases significantly as a result of internalisation of the receptor and of uncoupling. ${ }^{9}$ Consequently, adrenergic stimulation results in progressively less adenylate cyclase activity and cAMP formation. Moreover, there is enhanced expression of the inhibitor subunit of the guanine-nucleotidebinding regulatory proteins, $\mathrm{G}_{\mathrm{i} \alpha},{ }^{10} 11$ which reduces cAMP formation. This increase in the level of $G_{i \alpha}$ is unrelated to muscarinic $M_{2}$ or $A_{1}$ adenosine receptor activity. ${ }^{12}$ Furthermore, stimulation of adenylate cyclase by colforsin may be reduced in heart failure. ${ }^{13}$ Consequently, not only is basal cAMP formation decreased in heart failure but also the potential to stimulate it pharmacologically is diminished.

Initially, a specific decrease in the $\beta_{1}$ subtype was assumed, leading to a $50-70 \%$ downregulation of $\beta$ receptors. ${ }^{14}$ By contrast, $\beta_{2}$ receptors were not believed to be downregulated, suggesting a potential therapeutic role. Recent studies by Bristow et al indicate, however, that moderate (25-35\%) uncoupling of $\beta_{2}$ receptors occurs in heart failure, ${ }^{15}$ albeit predominantly in patients with ischaemic cardiomyopathy. These authors suggested that the regulatory behaviour of components of the $\beta$ receptor $G$ protein-adenylate cyclase axis differed between idiopathic dilated and ischaemic cardiomyopathy, with $\beta_{1}$ receptor downregulation in the first and uncoupling of $\beta_{2}$ receptors in the latter patient group. ${ }^{9}$ Moreover, the increase in $\mathrm{G}_{\mathrm{i} \alpha}$ may occur only in idiopathic cardiomyopathy. ${ }^{16}$

Consequently, changes linked to the $\beta$ adrenergic receptor in heart failure have important effects on cAMP formation in the heart. Deficient cAMP production undoubtedly is an important cause of contractile dysfunction in heart failure and of the lack of therapeutic efficacy of cAMP dependent positive inotropic support.

Moreover, the high adrenergic drive during heart failure which leads to these receptor changes also causes marked depletion of neurotransmitters in the heart. Both in idiopathic dilated cardiomyopathy and in ischaemic cardiomyopathy, tissue noradrenaline, adrenaline, dopamine, and neuropeptide $\mathrm{Y}$ concentrations are decreased. ${ }^{9}$ Consequently, indirect acting $\beta$ agonists, such as dopexamine and dopamine, lose their efficacy over time.

By contrast, cAMP independent inotropic mechanisms are possibly less affected by intrinsic cardiac changes. For instance, 
myocardial $\alpha$ adrenergic receptor density is unchanged in heart failure. ${ }^{17}{ }^{18}$ Although this could be important because $\alpha$ adrenergic stimulation elicits a positive inotropic response in humans, a diminished inotropic response has, nevertheless, been observed in heart failure, either as a result of receptor uncoupling or secondary to a general defect in the contractile potential in this condition. ${ }^{19} \mathrm{By}$ contrast, calcium sensitisation remains intact even in advanced stages of failure, and there is no evidence for a diminished efficacy of digitalis in advanced heart failure, at least not in in vitro experiments. Similarly, there are no data to indicate that sodium channel stimulation or other cAMP independent ways to increase intracellular calcium concentrations lose their inotropic efficacy in end stage heart failure.

\section{Clinical efficacy of cAMP dependent inotropic agents \\ SYMPATHOMIMETIC AGENTS (TABLE)}

Sympathomimetic agents are undoubtedly one of the cornerstones of the treatment of acute heart failure, particularly in low output conditions and in cardiogenic shock. Parenterally administered $\beta_{1}$ and $\beta_{2}$ adrenergic agents, dopamine, and, possibly, colforsin have clearly shown acute haemodynamic and clinical efficacy.

The effect is, however, comparatively short lived. Tolerance may occur after days, probably due to reduced $\beta$ receptor responsiveness secondary to further receptor downregulation, an increase in $\mathrm{G}_{\mathrm{i} \alpha}$, and possibly also inactivation of the adenylate cyclase system. Consequently, the capacity of the heart to produce cAMP diminishes. Although early studies suggested a sustained clinical improvement lasting for several weeks after a three day infusion of dobutamine, such improvement was observed only in a minority of patients and then specifically in those with a fairly well preserved function at baseline. Subsequent attempts to obviate long term

Clinically evaluated positive inotropic agents

\begin{tabular}{|c|c|c|}
\hline Sympathomimetic agents & Phosphodiesterase inhibitors & $\begin{array}{l}\text { Agents affecting membrane } \\
\text { pumps or channels }\end{array}$ \\
\hline $\begin{array}{l}\text { Non-selective: } \\
\text { Noradrenaline ( } \alpha \text { and } \beta) \\
\text { Adrenaline }(\alpha \text { and } \beta) \\
\text { Isoprenaline }(\beta)\end{array}$ & \multirow{6}{*}{$\begin{array}{l}\text { Predominant phosphodiesterase } \\
\text { inhibitors: } \\
\text { Amrinone } \\
\text { Milrinone } \\
\text { Enoximone } \\
\text { Piroximone } \\
\text { Adibendan } \\
\text { Imazodan } \\
\\
\text { Partial phosphodiesterase } \\
\text { inhibitors/calcium sensitisers: } \\
\text { Sulmazole } \\
\text { Pimobendan } \\
\text { Isomazole } \\
\text { UK-61 260 } \\
\text { Org } 30029 \\
\text { MCI-154 }\end{array}$} & $\begin{array}{l}\text { Sodium channel } \\
\text { stimulants: } \\
\text { DPI 201-106 (partial } \\
\text { calcium sensitiser) } \\
\text { PD } 122860\end{array}$ \\
\hline $\begin{array}{l}\text { Predominant } \beta_{1} \text { agonists: } \\
\text { Dobutamine } \\
\text { Prenalterol (partial agonist) } \\
\text { Xamoterol (partial agonist) }\end{array}$ & & \multirow{4}{*}{$\begin{array}{l}\text { Vesnarinone } \\
\text { (partial phospho- } \\
\text { diesterase inhibitor; } \\
\text { affects outward and } \\
\text { inward rectifying } \\
\text { potassium current) } \\
\text { Sodium-potassium } \\
\text { ATPase inhibitors: } \\
\text { Digitalis glycosides }\end{array}$} \\
\hline $\begin{array}{l}\text { Predominant } \beta_{2} \text { agonists: } \\
\text { Dopexamine (partial } \\
\text { dopaminergic) }\end{array}$ & & \\
\hline $\begin{array}{l}\text { Salbutamol } \\
\text { Pirbuterol } \\
\text { Terbutaline }\end{array}$ & & \\
\hline $\begin{array}{l}\text { Dopamine and } \beta_{1} \text { agonists: } \\
\text { Dopamine } \\
\text { Levodopa } \\
\text { Ibopamine }^{\star}\end{array}$ & & \\
\hline $\begin{array}{l}\text { Adenylate cyclase stimulant: } \\
\text { Colforsin }\end{array}$ & & \\
\hline
\end{tabular}

*Possibly only dopaminergic at clinically relevant dosages (see text). tolerance by intermittent dobutamine administration provided some clinical efficacy, as measured by exercise capacity and clinical improvement, although baseline ventricular function remained unchanged. ${ }^{20}$ Again, the improvement was observed in patients with less severe heart failure (New York Heart Association class III). In contrast, in patients with more severe failure, for whom such treatment would be more relevant, clinical improvement has not been impressive and mortality may be increased despite initial haemodynamic improvement.

Orally active sympathomimetic agents have not proved to be successful either. The $\beta_{1}$ agonist prenalterol, although resulting in initial haemodynamic and clinical improvement, did not lead to sustained benefit, and its use has long been discarded. Also, long term results with predominantly $\beta_{2}$ agonists, such as pirbuterol, terbutaline, and salbutamol, which in addition have some $\beta_{1}$ agonist properties, have not been favourable. Whereas early haemodynamic improvement was commonly present, this did not persist and long term clinical efficacy was inconsistent. ${ }^{21} 22$ Higher doses to improve efficacy have caused side effects, such as tremulousness or serious ventricular arrhythmias. ${ }^{23}$ As a result, orally active $\beta_{2}$ agonists are currently not used to treat heart failure.

In contrast, the partial $\beta_{1}$ agonist and antagonist xamoterol has, for some time at least, been considered a useful addition to the therapeutic armamentarium in mild heart failure. Xamoterol probably does have a valuable role as an alternative to diuretics or in patients with heart failure and atrial fibrillation. It may have a special role in elderly patients with heart failure. Xamoterol may also be an excellent choice in patients with heart failure and angina. Indeed, amelioration of ischaemic left ventricular dysfunction rather than heart failure itself may be its principal mode of action. A controlled study in severe heart failure failed to show clinical improvement but showed that xamoterol increased mortality. ${ }^{24}$ Preliminary reports in patients with milder heart failure suggest a neutral or slightly favourable effect on survival.

\section{DOPAMINERGIC AGENT}

In acute heart failure dopamine is extensively used in low output conditions to improve renal flow at lower doses and to improve cardiac output and blood pressure at higher doses. This reflects the pharmacological profile of the drug, which includes stimulation of dopaminergic 1 and 2 receptors and, at higher dosages, activation of $\beta_{1}, \alpha_{1}$, and $\alpha_{2}$ receptors. However, the major inotropic mechanism of action seems to be through cardiac adrenergic neurotransmittor release. ${ }^{25}$ As noradrenaline stores become depleted in the course of failure the positive inotropic effect of dopamine diminishes.

The orally active dopaminergic agents, levodopa and ibopamine, have a similar profile and have positive inotropic effects as well as 


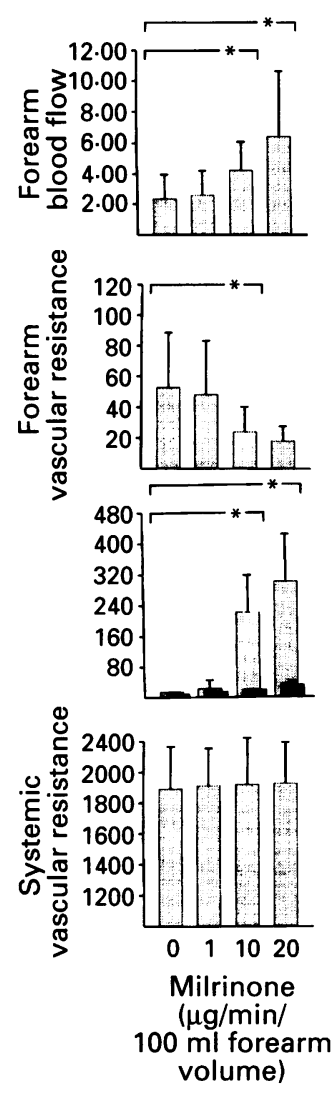

Figure 2 Regional vasodilator effect of locally administered milrinone. Forearm blood flow increases and forearm vascular resistance decreases parallel to incremental dosages of milrinone, which result in detectable milrinone concentrations in forearm venous blood ( ) but undetectable circulating concentrations $(\mathbf{Q}) .^{28}$ Reproduced with permission. vasodilator actions on renal, cerebral, coronary, and visceral beds (postsynaptic dopaminergic-1 action), and modulating effects on noradrenaline release from nerve endings (presynaptic dopaminergic- 2 action). Evidence in humans that these agents affect contractility under standard pharmacological concentrations is scarce. Recent data suggest that ibopamine, the only orally active dopaminergic agent available for clinical use, may be a (renal) vasodilator rather than a positive inotropic agent. ${ }^{26}$

\section{CAMP PHOSPHODIESTERASE INHIBITORS}

By contrast to the lack of inotropic effects of orally active dopaminergic agents, cAMP phosphodiesterase (PDE) inhibitors clearly improve cardiac contractility in humans, shown when agents such as milrinone are introduced into the coronary circulation. ${ }^{27}$ PDE inhibitors are also potent vasodilators, as may be observed after intra-arterial administration in heart failure (fig 2). ${ }^{28}$ Consequently, PDE inhibitors are better classified as inodilators than positive inotropic agents. ${ }^{29}$ Venodilating properties may predominate with these compounds, at least at lower doses, ${ }^{30} 31$ and, in patients with normal to low ventricular filling pressures as a result of diuretic treatment, PDE inhibition may reduce cardiac output by reducing filling pressures still further, an effect which resembles that of nitrates under similar conditions (fig 3 ). ${ }^{32}$

In addition, tolerance to their vasodilating properties may occur. After long term treatment with milrinone in patients with moderate heart failure, the initial improvement in pump function disappears, whereas after withdrawal, cardiac output decreases and systemic resistance increases beyond pretreatment values. ${ }^{33}$ This rebound phenomenon may reflect neurohormonal activation during milrinone treatment.

Whether or not related to haemodynamic tolerance, there is ample evidence that clinical efficacy with predominant PDE inhibitors is not sustained. In placebo controlled studies

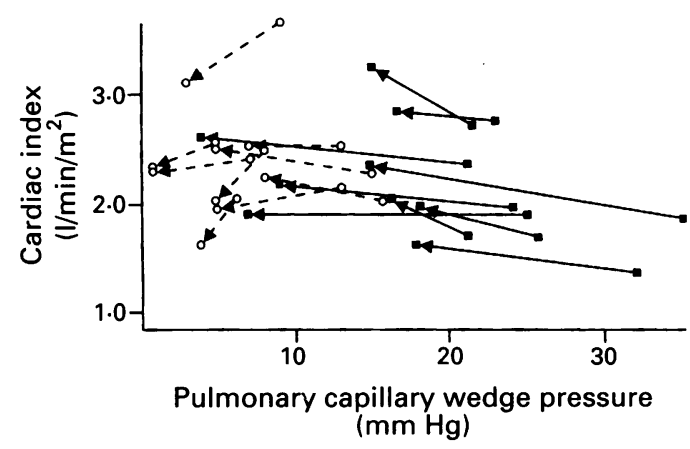

Figure 3 Effect of oral milrinone $(10 \mathrm{mg})$ on cardiac pump function in nine patients with heart failure and raised left ventricular filling pressures (PCWP) ( $\square$;

$P C W P \geqslant 18 \mathrm{~mm} \mathrm{Hg}$ ) and nine patients with heart failure and normal left ventricular filling pressures $(O ; P C W P$ $<18 \mathrm{~mm} \mathrm{Hg}$. (Heart failure was class II-III according to classification of New York Heart Association.) Cardiac index improves in the first group but falls in the second. ${ }^{32}$ Reproduced with permission. with agents such as amrinone and enoximone significant improvements in exercise capacity or clinical wellbeing have not been sustained. ${ }^{34}{ }^{35}$ One study that compared milrinone, digoxin, their combination, and placebo in patients with class III heart failure (New York Heart Association's classification) suggested an improvement with the PDE inhibitor. ${ }^{36}$ However, in this study, all patients were initially taking digoxin, which was withdrawn before randomisation. Although patients taking milrinone had better exercise capacity than the patients who received placebo, when they were compared with patients who continued to take digoxin there was no such effect. Rather than supporting the efficacy of milrinone, this study would favour the use of digoxin in moderate to severe heart failure.

\section{Clinical efficacy of cAMP independent inotropes}

CALCIUM SENSITISERS

By contrast to predominant PDE inhibitors, late haemodynamic tolerance may not be a problem with the few available calcium sensitisers, which all share some PDE inhibiting effects (table). Pimobendan, a calcium sensitiser and partial PDE inhibitor and the most extensively studied compound in this category, retains its vasodilating capacity and haemodynamic efficacy for at least six months in patients with moderate heart failure. ${ }^{37}$ This indicates that long term haemodynamic effects may differ between predominant PDE inhibitors and compounds which share calcium sensitising and PDE inhibiting properties. Also, long term clinical efficacy may differ. Available controlled studies indicate an improvement in exercise capacity, peak oxygen consumption, and heart failure status after treatment lasting between three and six months. ${ }^{38-40}$ Whereas this may already be true for fairly high doses of pimobendan, it is interesting to note that clinical efficacy is better with low to intermediate doses. ${ }^{39}$ Whether this reflects relatively less PDE inhibition at lower doses is as yet purely speculative.

Theoretically, calcium sensitisation may further slow the process of myocardial relaxation, which is already impaired in heart failure. In myopathic tissue the capacity to restore normal concentrations of cytosolic calcium during diastole is diminished. Consequently, both resting intracellular calcium concentrations and diastolic developed force are higher than in normal cardiac muscle. As this negatively affects contractile force, "pure" calcium sensitisers may further decrease contractile reserve in addition to their effect on relaxation. ${ }^{3}$ This is, however, less likely for the calcium sensitisers currently available, which all have additional PDE inhibiting properties. Pimobendan, administered intravenously to patients with heart failure (New York Heart Association class II-III) and ischaemic cardiomyopathy, impairs neither ventricular relaxation nor contractility (fig 4). Instead, isovolumetric relaxation indices improve, 

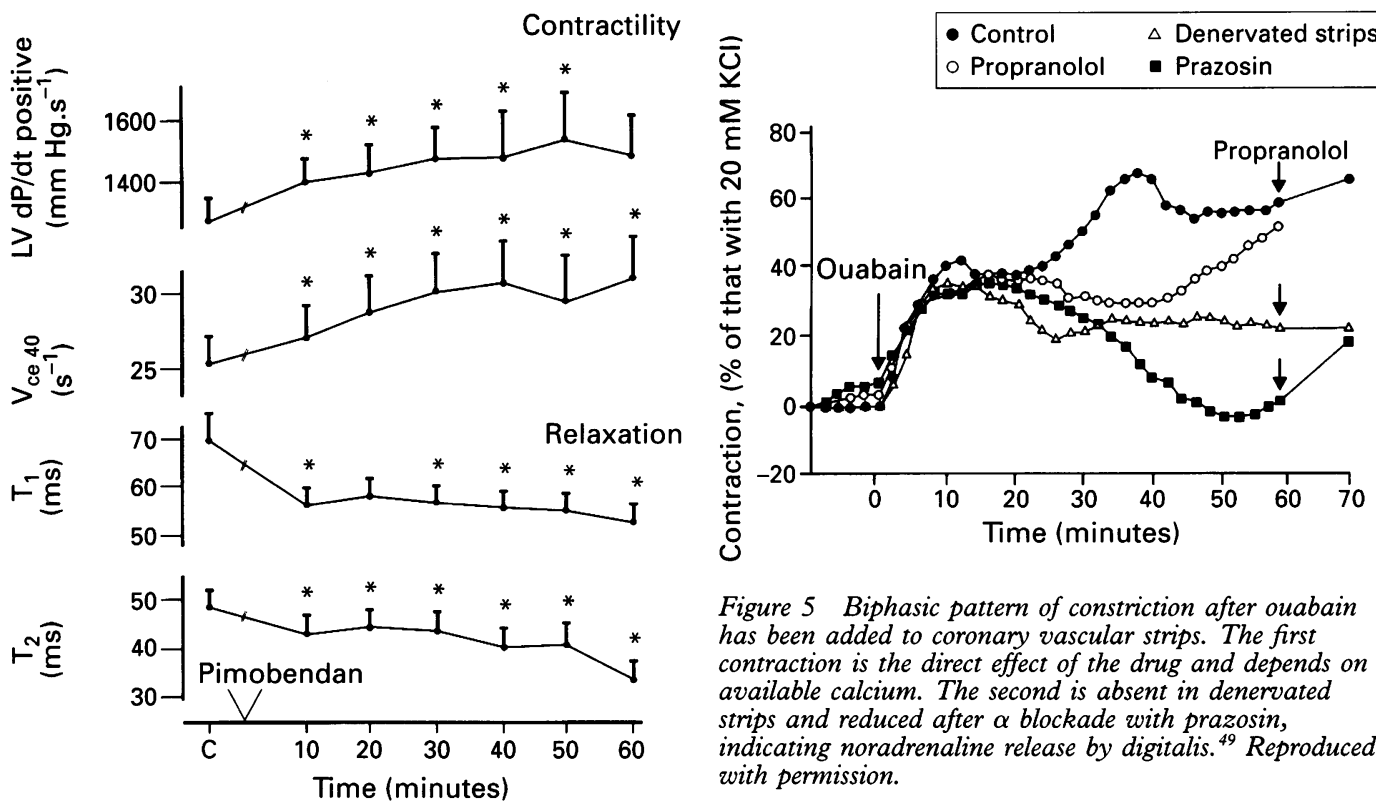

Figure 5 Biphasic pattern of constriction after ouabain has been added to coronary vascular strips. The first contraction is the direct effect of the drug and depends on available calcium. The second is absent in denervated strips and reduced after $\alpha$ blockade with prazosin, indicating noradrenaline release by digitalis. ${ }^{49}$ Reproduced with permission.

Figure 4 Acute, but sustained improvement of isovolumetric indices of contractility ( $L V d P / d t$ positive and $\left.V c e_{40}\right)$ and relaxation $\left(T_{1}\right.$ and $\left.T_{2}\right)$ after $10 \mathrm{mg}$ intravenous pimobendan in patients with ischaemic cardiomyopathy and moderate heart failure. During the measurements heart rate was fixed by way of atrial pacing. ( $T$, tau (relaxation time constant).)

which, together with its acute vasodilating effects under these conditions, may represent the additional PDE inhibiting properties of this compound. ${ }^{41}$ Myocardial energetics are also favourably affected with a decrease in myocardial oxygen consumption. This contrasts with predominant cAMP dependent interventions - that is, xamoterol and enoximone-which under similar conditions increase oxygen consumption or leave it unaffected. ${ }^{42} 43$

SODIUM CHANNEL STIMULANTS

The few available sodium channel stimulants (table) have additional vasodilating properties, although they primarily induce positive inotropic effects through sodium channel stimulation and subsequent sodium-calcium exchange. ${ }^{44}$ Like the available calcium sensitisers, this suggests that these agents should be considered inodilators rather than pure positive inotropes.

The most intensively studied sodium channel stimulant in humans is OPC 8212 (vesnarinone); it was recently shown to enhance survival in patients with severe heart failure when given in low doses. ${ }^{46}$ This interesting and unexpected finding for a positive inotrope may relate to the additional pharmacological properties of this rather complex molecule. Besides sodium channel stimulating effects and mild, selective PDE inhibition, vesnarinone decreases the delayed outward and inward rectifying potassium currents. The latter are probably involved in the antitachycardiac effects of vesnarinone, observed after sympathetic stimulation, and in the prolongation of the action potential. ${ }^{47}$ Whether this implies that vesnarinone should be considered a class III antiarrhythmic agent

rather than an inotrope, and, consequently, the effects on mortality the result of an antiarrhythmic effect, is uncertain. Firstly, Feldman et al found that the reduction in mortality applied not only to patients dying suddenly but also to patients dying of progressive failure. ${ }^{46}$ Moreover, vesnarinone reduced the risk of worsening heart failure and improved quality of life. Secondly, available antiarrhythmic agents have thus far not appreciably affected mortality in progressive heart failure. The reasons for the unexpected beneficial effect of vesnarinone on survival and heart failure status are not clear, but they may include the combination of cAMP independent inotropic effects, antiarrhythmic properties, a bradycardiac effect, and, possibly, an inhibiting action on cytokine production. ${ }^{48}$

There is some concern, though. Vesnarinone induces agranulocytosis in $2.5 \%$ of patients. Moreover, as will be discussed below, it probably has a narrow therapeutic range, like digitalis. ${ }^{46}$

\section{DIGITALIS GLYCOSIDES}

Digitalis glycosides inhibit the activity of membrane sodium-potassium ATPase. This results in raised intracellular sodium, which is exchanged for calcium through the sodiumcalcium exchanger. In addition, the rise in intracellular calcium concentration leads to an increase in hydrogen ions, which are exchanged for sodium, in turn leading to more intracellular calcium. This results in enhanced cardiac contractility and vasoconstriction.

In vitro, the vasocontrictor effects of digitalis are biphasic. ${ }^{49}$ Firstly, there is a contraction which depends on available calcium and reflects the direct constrictor effect of the drug. This is followed by a second vasoconstriction, which is lost in denervated vascular strips and reduced by coadministration of the $\alpha_{1}$ blocker prazosin, probably by digitalis induced release of noradrenaline from nerve endings (fig 5). In vivo these direct vasoconstrictor effects of 
digitalis are augmented through central stimulation of sympathetic tone. ${ }^{50}$

In subjects with normal cardiac function digitalis has a vasoconstrictor effect, although this depends on dose and rate of administration. Intravenous administration of ouabain for 10 seconds or two minutes causes a significant increase in systemic vascular resistance but not when a slower infusion rate is applied. ${ }^{51}$ In subjects without heart failure an intravenous bolus administration of digoxin results in coronary vasoconstriction with a significant reduction in the cross sectional area of both normal segments and arteries with coronary artery disease. ${ }^{52}$

In heart failure the acute vasoconstrictor action of digitalis is counteracted by the modulating effects of digitalis on neurohormonal activation and by its sympathoinhibitory activity. Thus, in patients with heart failure digitalis may induce vasodilatation through direct or indirect attenuation of neuroendocrine activation. In addition to earlier observations by Mason and Braunwald of the peripheral vasodilating effects of ouabain in patients with heart failure and of vasoconstriction in normal subjects, ${ }^{50}$ Ferguson et al recently showed that short term treatment with digitalis reduces sympathetic nerve activity, resulting in systemic vasodilatation in patients with heart failure but not in normal subjects. ${ }^{53}$ Glycosides increase baroreceptor sensitivity, both in normal subjects and in patients with heart failure. Underlying mechanisms may include direct receptor stimulation, an effect related to inhibition of sodium-potassium ATPase, or a secondary response to improved haemodynamics. The findings of Ferguson et al suggest a direct effect, as sympathoinhibitory effects occurred before haemodynamic changes were apparent. $^{53}$

Short term treatment with digitalis also leads to a reduction in circulating catecholamine concentrations, plasma renin activity, and aldosterone concentrations. In addition, in vitro data indicate that ouabain may stimulate secretion of atrial natriuretic peptide from atrial cardiocytes. ${ }^{54}$ Recently the Dutch ibopamine multicentre trial, a six month comparison of ibopamine, digoxin, and placebo in patients with moderate heart failure taking diuretics, indicated that digoxin also significantly decreases circulating noradrenaline and renin concentrations. ${ }^{55}$ Thus, digitalis emerges as an interesting drug for managing heart failure, as it combines both cAMP independent positive inotropic properties and neurohormonal modulating effects.

But does it work in clinical practice? There is little doubt about its efficacy in patients with heart failure and atrial fibrillation, partly because of its vagotonic effect. By contrast, despite its early recognition as a therapeutic agent for dropsy ${ }^{56}$ and the elaborate studies by Withering, ${ }^{57}$ its usefulness in heart failure and sinus rhythm has been and still is being debated. Whereas long term haemodynamic improvement is clear, many studies that have explored the clinical effects of digoxin have not shown convincing benefit. ${ }^{58-64}$ Few adequate controlled studies of digoxin exist. Several included only patients in whom digitalis could be withdrawn, hence introducing bias. Enrolment criteria often were not well defined-for example, the presence of systolic dysfunction and background treatment were not controlled for or specified and sample size was often inadequate.

A few studies have indicated that the addition of digitalis to existing treatment or its withdrawal under controlled conditions leads to clinical improvement or deterioration, respectively. ${ }^{65-67}$ Patients with heart failure and sinus rhythm who improved tended to be those with systolic dysfunction, large hearts, an S3 gallop, and heart failure (New York Heart Association class III) despite treatment. By contrast, the Dutch ibopamine multicentre trial suggested that digoxin exerted clinical benefits even in patients with moderate heart failure who were treated only with diuretics. ${ }^{55}$ Two recent studies in patients with mild to moderate heart failure and sinus rhythm indicate that such patients also tend to deteriorate after abrupt withdrawal of digitalis. ${ }^{6869}$ The RADIANCE study is particularly noteworthy in this respect, as all patients in this study, in contrast to previous investigations with digitalis, were taking ACE inhibitors $^{69}$ (fig 6). Thus, when clinical efficacy is concerned, it makes sense to give digitalis to patients with comparatively severe heart failure and sinus rhythm despite the accepted standard treatment of diuretics and ACE inhibitors. Also, it makes sense to continue digitalis when such patients have improved to a milder stage of heart failure. But how safe is digoxin?

\section{What if digoxin increases mortality?}

Despite centuries of use, doctors do not know whether digitalis has an effect on mortality and whether this is favourable. Arrhythmias are a well recognised manifestation of digitalis toxicity. The therapeutic-toxic dose range is quite narrow under normal conditions; aging, abnormal renal haemodynamics, and the propensity for hypokalemia in heart failure may clearly enhance the potential for toxicity.

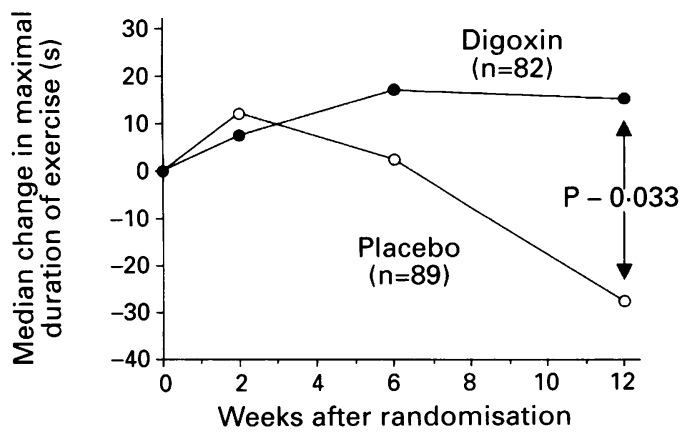

Figure 6 Worsening of exercise capacity in patients with mild heart failure previously taking digoxin, diuretics, and ACE inhibitors in whom digoxin was replaced by placebo. The comparison group continued to take digoxin. Reproduced with permission. 
As suggested above, the clinical efficacy of digitalis is probably better in more severe conditions where pharmacokinetic aspects could be more disadvantageous. Yet, several fairly large comparative studies of digitalis in patients with severe heart failure did not report a significant increase in ventricular ectopic activity. ${ }^{636670}$ Moreover, a proarrhythmic effect does not necessarily lead to increased mortality in heart failure.

Digitalis could also beneficially affect survival by improving cardiac function, by its sympathoinhibitory and neurohormonal modulating effects, and by its parasympathomimetic properties. Its inotropic effect may primarily occur at higher doses and its neurohormonal effect at lower doses. ${ }^{71}$ Although this assumes less detrimental effects with low dose digitalis-in line with the experiences with vesnarinone and possibly enoximonethis is still speculative.

As with other positive inotropes, a large trial of digoxin is needed to assess its effects on survival at different stages of heart failure, preferably with monitoring of serum digoxin concentrations and against the background of currently accepted treatment for heart failure. Such a study is presently being conducted in over 8000 patients-the DIG trial. If this trial shows a favourable effect of digoxin on survival then it is likely that all patients with established heart failure will be treated with digoxin and an ACE inhibitor, diuretics retaining their role when fluid retention is a problem. If digoxin's effect on mortality is neutral then the knowledge that digoxin is safe will also lead to more widespread use. On the other hand, if digoxin increases mortality use will decline. Most of the properties that have been imputed to digoxin at one time or another have already been proved with ACE inhibitors: symptomatic improvement, delays in the deterioration of heart failure, and increased survival. However, digoxin seems to have a role in improving symptoms in addition to that of an ACE inhibitor. Many physicians may wish to continue to use digoxin in severe heart failure, believing that the relief of symptoms is a sufficient reward for the increase in mortality. This is similar to what recently happened with flosequinan, a new agent for heart failure. The medicolegal position in that case was considered to be untenable, and the drug was withdrawn. Will a similar situation develop with digoxin, the medicolegal threat not being to a pharmaceutical company but to prescribing doctors?

1 Allen DG, Kurihara S. Calcium transients in mammalian ventricular muscle. Eur Heart f 1980;1(suppl A):5-15.

2 Schramm M, Thomas G, Towart R, Franchowiak G. Novel dihydropyridines with positive inotropic action through activation of $\mathrm{Ca}^{2+}$ channels. Nature 1983;303:535-7.

3 Hajjar RJ, Gwathmey JK. Calcium-sensitizing inotropic agents in the treatment of heart failure: a critical view. Cardiovascular Drugs and Therapy 1991;5:961-6.

4 Holubarsch C, Hasenfuss G, Just H, Blanchard E, Mulieri LA, Alpert NR. Influence of the positive inotropic substance pimobendan (UD-CG $115 \mathrm{BS}$ ) on contractile economy of guinea pig papillary muscles. $f$ Cardiovasc economy of guinea pig papillary m
Pharmacol $1989 ; 14$ (suppl 2):S13-7.

5 Scheld HH, Fritsche R, Schlepper M, Van Meel JCA Pimobendan increases calcium sensitivity of skinned human papillary muscle fibres. $f$ Clin Pharmacol 1989;29:360-5

6 Wilkie DR. Muscular fatigue: effects of hydrogen ions and inorganic phosphate. Fed Proc 1986;45:2921-3.

7 Silver PJ, Allen P, Etzler JH, Hamel LT, Bentley RG Pagani ED. Cellular distribution and pharmacological sensitivity of low $\mathrm{Km}$ cyclic nucleotide phosphodiesterase isozymes in human cardiac muscle from normal and cardiomyopathic subjects. Second-Messengers-Phosphoproteins 1990;13:13-25.

8 Böhm M, Diet F, Feiler G, et al. Subsensitivity of the failing human heart to isoprenaline and milrinone is related to beta-adrenoceptor downregulation. $\mathscr{f}$ Cardiovasc Pharmacol 1988;12:726-32.

9 Bristow MR, Anderson FL, Port JD, et al. Differences in $\beta$ adrenergic neuroeffector mechanisms in ischemic versus idiopathic dilated cardiomyopathy. Circulation 1991;84: 1024-39.

10 Feldman AM, Cates AE, Veazey WB, et al. Increase in the $40,000-$ mol wt pertussis toxin substrate (G-protein) in the failing human heart. $\mathcal{F}$ Clin Invest 1988;82:189-97.

11 Eschenhagen $T$, Mende U, Nose $M$, et al. Increased messenger RNA level of the inhibitory $G$ protein a subunit $\mathrm{G}_{\mathrm{i \alpha}-2}$ in human end-stage heart failure. Circ Res subunit $G_{\text {iu-2 }}$ in

12 Böhm M, Ungerer M, Erdmann E. Beta adrenoceptors and $\mathrm{m}$-cholinoceptors in myocardium of hearts with coronary m-cholinoceptors in myocardium of hearts with coronary artery disease or idiopathic dilated cardiomyopathy removed at cardic

13 Schnabel P, Böhm M, Gierschik P, Jakobs KH, Erdmann E. Improvement of cholera toxin-catalysed ADPribosylation by endogenous ADP-ribosylatin factor from bovine brain provides evidence for an unchanged amoun of $\mathrm{G}_{\mathrm{sa}}$ in failing human myocardium. $\mathcal{f} \mathrm{Mol}$ Cell Cardio 1990;22:73-82.

14 Bristow MR, Ginsburg R, Umans V, et al. Beta ${ }_{1}$ and beta adrenergic receptor subpopulations in nonfailing and failing human ventricular myocardium: coupling of both receptor subtypes to muscle contraction and selective beta receptor down-regulation in heart failure. Circ Res 1986;59:297-309.

15 Bristow MR, Hershberger RE, Port JD, Rasmussen R. $\beta_{1}$ and $\beta_{2}$ adrenergic receptor-mediated adenylate cyclase stimulation in nonfailing and failing human ventricular myocardium. f Mol Pharmacol 1989;35:295-303.

16 Böhm M, Gierschik P, Jakobs K-H, et al. Increase of $G_{i \alpha}$ in human hearts with dilated but not ischemic human hearts with dilated but not

17 Bristow MR, Minobe W, Rasmussen R, Hershberger RE Hoffman BB. Alpha-1 adrenergic receptors in the nonfailing and failing human heart. $\mathcal{F}$ Pharmacol Exp Ther 1988;247:1039-45.

18 Böhm M, Diet F, Feiler G, Kemkes B, Erdmann E. a Adrenoceptors and $\alpha$ adrenoceptor-mediated positive inotropic effects in failing human myocardium. $\mathcal{f}$ Cardiovasc Pharmacol 1988;12:357-64.

19 Landzberg JS, Parker JD, Gauthier DF, Colucci WS Effects of myocardial $\alpha_{1}$-adrenergic receptor stimulation and blockade on contractility in humans. Circulation 1991;84:1608-14

20 Leier CV, Huss P, Lewis RP, Unverferth DV. Druginduced conditioning in congestive heart failure. Circulation 1982;65:1382-7.

21 Weber KT, Andrews V, Janicki JS, Likoff M, Reichek N. Pirbuterol, an oral beta-adrenergic receptor agonist, in the treatment of chronic cardiac failure. Circulation 1982;66:1262-7.

22 Colucci WS, Alexander WR, Williams GH, et al. Decreased lymphocyte beta-adrenergic-receptor density in patients with heart failure and tolerance to the beta-adrenergic with heart failure and tolerance to the beta-adren

23 Mettayur B, Rouleau J-L Burgess JH. Detrimental arrhythmogenic and sustained beneficial hemodynamic arfhythmogenic and sustained beneficial hemodynamic congestive heart failure. Am Heart $¥ 1985 ; 109: 840-7$.

24 Xamoterol in Severe Heart Failure Study Group. Xamoterol in severe heart failure. Lancet 1990;336:1-6.

25 Anderson FL, Port JD, Reid BB, et al. Effect of therapeutic dopamine administration on myocardial catecholamine and neuropeptide $\mathrm{Y}$ concentrations in the failing ventricles of patients with idiopathic cardiomyopathy. $\mathcal{J}$ Cardiovasc Pharmacol 1992;20:800-6.

26 Rousseau MF, Raigoso J, Van Eyll C, et al. Effects of intravenous epinine administration on left ventricula systolic performance, coronary hemodynamics and circulating catecholamines in patients with heart failure. f Cardiovasc Pharmacol 1992;19:155-62.

27 Ludmer PL, Wright RF, Arnold JMO, Ganz P, Braunwald E, Colucci WS. Separation of the direct myocardial and vasodilator actions of milrinone administered by an intracoronary infusion technique. Circulation 1986;73. $130-7$.

28 Cody RJ, Muller FB, Kubo SH, Rutman H, Leonard D. Identification of the direct vasodilator effect of milrinone with an isolated limb preparation in patients with chronic with an isolated limb preparation in patients with chron

29 Remme WJ. Inodilator therapy for heart failure. Early, late or not at all? Circulation 1993;87(suppl IV):IV-97-107.

or not at all? Circulation 1993;87 (suppl IV):IV-97-107.
30 Muir AL, Nolan J. Modulation of venous tone in heart failure. Am Heart f 1991;121:1948-50.

31 Borow KM, Come PC, Neumann A, Baim DS, Braunwald E, Grossman W. Physiologic assessment of the inotropic, vasodilator and afterload reducing effects of milrinone in 
subjects without cardiac disease. $A m \quad \mathcal{F}$ Cardiol 1985;55:1204-9.

32 Remme WJ, Van Hoogenhuyze DCA, Krauss XH Kruyssen HACM, Pieper PG, Bruggeling WAJ. Preloaddependent hemodynamic effects of milrinone moderate heart failure. Cardiology 1992;80:132-42.

33 Remme WJ. Vasodilator therapy without converting enzyme inhibition in congestive heart failure-usefulness and

34 Massie B, Bourassa M, DiBianco R, Hess M, Konstam M, Likoff $M$, et al for the Amrinone Multicentre Study Group. Long-term oral administration of amrinone for congestive heart failure: lack of efficacy in a multicenter congestive heart failure: lack of efficacy in a
controlled trial. Circulation 1985;71:963-71.

35 Uretsky BF, Jessup M, Konstam MA for the Enoximone Multicenter Trial Group. Multicenter trial of oral enoximone in patients with moderate to moderately severe congestive heart failure. Lack of benefit compared with placebo. Circulation 1990;82:774-80.

36 DiBianco R, Shabetai R, Kostuk W, Moran J, Schlant RC Wright R. A comparison of oral milrinone, digoxin and their combination in the treatment of patients with chronic heart failure. N Engl f Med 1989;320:677-83.

37 Assmann I, Kassel P, Duck HG, et al. Akut- und Langzeiteffekte von Pimobendan (UD-CG 115) be Herzinsuffizienz NYHA II und III. Ergebnisse einer
randomisierten multizentrischen Doppelblindstudie. $Z$ Kardiol 1991;80:687-94.

38 Katz SD, Kubo SH, Jessup $M$, et al. A multicenter, randomized, double-blind, placebo-controlled trial of pimobendan, a new cardiotonic and vasodilator agent, in patients with severe congestive heart failur. Am Heart $\mathcal{f}$ 1992;123:95-103.

39 Kubo SH, Gollub S, Bourge R, et al for the Pimobendan Multicenter Research Group. Beneficial effects of pimobendan on exercise tolerance and quality of life in patients with heart failure. Results of a multicenter trial. Circulation 1992;85:942-9.

40 Remme WJ, Krayenbühl HP, Baumann G, et al for the Pimobendan-Enalapril Study Group. Long-term efficacy Pimobendan-Enalapril Study Group. Long-term efficacy and safety of pimobendan in moderate heart failure. A double-blind parallel 6

41 Remme WJ, Wiesfeld ACP, Look MP, Kruyssen HACM Hemodynamic effects of intravenous pimobendan in patients with left ventricular dysfunction. $\mathcal{F}$ Cardiovas Pharmacol 1989;14(suppl 2):S41-4

42 Hasenfuss G, Holubarsch C, Heiss HW, Rattert B, Just H Influence of the calcium-sensitizer UDCG-115 on haemodynamics and myocardial energetics in patient with idiopathic dilated cardiomyopathy. Comparison with nitroprusside. Basic Res Cardiol 1989;84:225-33.

43 Hasenfuss G, Holubarsch C, Heiss W, et al. Myocardia energetics in patients with dilated cardiomyopathy. Influence of nitroprusside and enoximone. Circulation 1989;80:51-64.

44 Haleen SJ, Steffen RP, Sircar I, et al. PD 122,860: a novel dihydropyridine with sodium channel stimulating and calcium blocking properties. $\mathcal{F}$ Pharmacol Exp Ther 1989;250:22-30.

45 Holck $M$, Osterrieder W. Interaction of the cardiotonic agent DPI 201-106 with cardiac $\mathrm{Ca}^{2+}$ channels. I

46 Feldman AM, Bristow MR, Parmley WW, et al for the Vesnarinone Study Group. Effects of vesnarinone or morbidity and mortality in patients with heart failure. $N$ morbidity and mortality in pa

47 Yanagisawa T, Ishi K, Taira N. Antitachycardiac effect of OPC-8212, a novel cardiotonic agent, on tachycardiac responses of guinea pig isolated right atria to isoproterenol and histamine. 7 Cardiovasc Pharmaco 1987;10:47-54.

48 Busch FW, Tillmann A, Becker EW, Owsianowski M, Bers PA. The inhibitory effects of a positive inotropic quinolinone derivative, 3,4-dihydro-6-[4-(3,4-dimethoxybenzoyl)-1-piperazynyl]2(IH)-quinolinone (OPC8212 ), on bone marrow progenitor cells and peripheral lymphocytes. Eur f Clin Pharmacol 1992;42:629-33.

49 Cooke JP, Shepherd JT, Vanhoutte PM. Vasoconstriction induced by ouabain in the canine coronary artery:
contribution of adrenergic and nonadrenergic responses. Cardiovascular Drugs and Therapy 1988;2:255-63.
50 Mason DT, Braunwald E. Studies on digitalis. X. Effects of ouabain on forearm vascular resistance and venous tone in normal subjects and in patients in heart failure. f Clin Invest 1964;43:532-43.

51 DeMots H, Rahimtoola SH, McAnulty JH, Porter GA. Effects of ouabain on coronary and systemic vascular resistance and myocardial oxygen consumption in patients without heart failure. $A m \quad f$ Cardiol 1978;41:88-93.

52 Indolfi C, Piscione F, Russolillo E, et al. Digoxin-induced vasoconstriction of normal and atherosclerotic epicardial coronary arteries. Am $\mathcal{J}$ Cardiol 1991;68:1274-8.

53 Ferguson DW, Berg WJ, Sanders JS, Roach PJ, Kempf JS, Kienzle MG. Sympathoinhibitory responses to digitalis glycosides in heart failure patients. Circulation 1989;80:65-77.

54 Bloch KD, Zmir N, Lichtstein D, Seidman CE, Seidman JG. Ouabain induces secretion of pro-atrial natriuretic factor in rat atrial cardiocytes. Am $\mathcal{J}$ Physiol 1988;255:E383-7.

55 Van Veldhuisen DJ, Man in 't Veld AJ, Dunselman PHJM, et al. Double-blind placebo-controlled study of ibopamine and digoxin in patients with mild to moderate heart failure: results of the Dutch ibopamine multicenter trial (DIMT). $\mathcal{F}$ Am Coll Cardiol 1993;22:1564-73.

56 Jacobs M. A history of digitalis therapy. Annals of Medical Therapeutics 1936;492.

57 Withering W. An account of the foxglove and some of its medical uses - practical remarks on dropsy and other diseases. Birmingham: M Swinney, 1785.

58 Fleg L, Gottlieb SH, Lakatta EG. Is digoxin really important in compensated heart failure? $A m \mathcal{F}$ Med 1982;73:244-50.

59 Taggart AJ, Johnston GD, McDevitt DG. Digoxin withdrawal after cardiac failure in patients with sinus rhythm. I Cardiovasc Pharmacol 1983;5:229-34.

60 Guyatt GH, Sullivan MJJ, Fallen EL, et al. A controlled trial of digoxin in congestive heart failure. Am 7 Cardiol 1988;61:371-5.

61 Aronow WS, Starling L, Etienne F. Lack of efficacy of digoxin in treatment of compensated congestive heart failure with third heart sound and sinus rhythm in elderly patients receiving diuretic therapy. $A m \mathcal{F}$ Cardiol 1986;58:168-9.

62 German and Austrian Xamoterol Study Group. Doubleblind placebo-controlled comparison of digoxin and xamoterol in chronic heart failure. Lancet 1988; 489-93.

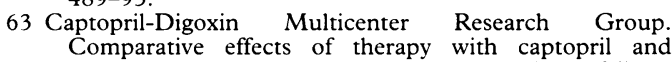
digoxin in patients with mild to moderate heart failure. IAMA 1988;259:539-44

64 Davies RF, Beanlands DS, Nadeau C, et al. Enalapril versus digoxin in patients with congestive heart failure: multicenter study. F Am Coll Cardiol 1991;18:1602-9.

65 Lee DC-S, Johnson RA, Bingham JB, et al. Heart failure in outpatients: a randomized trial of digoxin versus placebo. $N$ Engl F Med 1982;306:699-705.

66 DiBianco R, Shabetai R, Kostuk W, et al. A comparison of oral milrinone, digoxin, and their combination in the treatment of patients with chronic heart failure. $N$ Engl treatment of patients with

67 Fleg JL, Rothfeld B, Gottlieb SH. Effect of maintenance digoxin therapy on aerobic performance and exercise left ventricular function in mild to moderate heart failure due to coronary artery disease: a randomized, placebocontrolled crossover trial. $\not{f} \mathrm{Am}$ Coll Cardiol 1991;17: 743-51.

68 Uretsky BF, Young JB, Shahidi FE, Yellen LG, Harrison MC, Jolly KM. Randomized study assessing the effect of digoxin withdrawal in patients with mild to moderate chronic congestive heart failure: results of the PROVED trial. F Am Coll Cardiol 1993;22:955-62.

69 Packer M, Gheorghiade M, Young JB, et al. Withdrawal of digoxin from patients with chronic heart failure treated with angiotensin-converting enzyme inhibitors. $N$ Engl f Med 1993;329:1-7.

70 Lown B, Graboys TB, Podrid PJ, Cohen BH, Stockman MS, Gaugham LE. Effect of digitalis drug on ventricular premature beats. $N$ Engl f Med 1977;296:301-6.

71 Packer $M$. The development of positive inotropic agents for chronic heart failure: how have we gone astray? $\mathrm{f} \mathrm{Am} \mathrm{Coll}$ Cardiol 1993;22(suppl A):119-26A. 